\title{
THOUGHTS ON THE RESPONSIBILITY OF LEGAL ENTITIES IN EUROPE
}

\author{
Dimitris Liakopoulos \\ Fletcher Law School, Massachusetts Law School, De Haagse Hogenschool \\ prof.d.liakopoulos.984@gmail.com
}

\begin{abstract}
The present work is concentrated on a construction of a legal person's model responsibility for the EU countries, with a particular attention for a comparative analyse of the systems assumed in certain European nations (Italian, France, Spain, German, Belgian systems). The end result of this system is oriented to corporates responsibilities that, after the mass transfer of general interest from public service to privates services, corporates have to attend to relatives guarantees. Because it was established a social insecurity level, we have produced a model of corporation's organisation engaged of a security position, that exceed the traditional standard of culpability.
\end{abstract}

Keywords: EU Law; Corporate Responsibility; Responsibility Form Public Service; Public Culpability

\section{Introduction}

Starting from a terminological analysis of the word person, we try to circumscribe the object of the research within a linguistic dynamic of legal subjectivity ${ }^{12}$. In this perspective, a fundamentally normative definition is chosen which sees legal persons as entities capable of acting and producing legally relevant facts ${ }^{3}$. Considering that criminal law is a right of fact, that is, a right that subjects the facts arising from actions or material omissions to its own discipline, it has been deduced that the entities should be considered as subjects arising from an autonomous prejudicial phenomenon, proven by the existence of the so-called de facto bodies and the fact that their existence, thus determined, gives rise to socially observable facts. Of course, the observation that natural persons act materially within the collective body has given rise to many difficulties in the history of the dogmatic definition of legal persons. It is a question of knowing whether, when we speak of a legal person, we intend to refer to the individual set that makes it up, through a useful simplification of the legal mechanism, or to a collective unit with its own autonomy with respect to singular individualities. .

In this perspective, the traditional brocardo societas delinquere non potest has been called into question. This assumption, through a historical and political analysis of the conception of the

J.CH. 9 ed0 Saint-Pau, Traité Des Droits de La Personnalité (Paris: LexisNexis, 2013).

A. Boulanger, Restrucurations Sociètaires et Responsabilitè Pènale (Toulouse: Presses de l'Universitè, 2019).

M.A. Abanto Vàszquez, "Responsabilidad Penal de Los Entes Colectivos: Una Rèvision Critica de La Soluciones Penales," Revista Penal Mèxico 3 (2010): 124ss. 
legal person, has been partially refuted. It is not historically true that collective bodies have been excluded from the list of punishable individuals. Finally, the thesis was held according to which the law should respond to the social reality and the concrete needs of legal entities, that is, to the defense of the individual placed in the face of a dangerous world and a fundamentally unfair social organization.

\section{Methods}

This research adopts normative legal research method, with comparative and conceptual approaches. For comparative approach we mean a personal, critical analysis of thoughts that come from deeper research concentrated on a world level. The comparison comes mostly from the doctrine and some sources of European Union law. As for the conceptual approach, this is a descriptive research which describing data about a situation or social symptoms that develop in the midst of society, so that the existence of this study is expected to obtain a comprehensive, complete and systematic picture of the object of research. The data used that leads to studies that are theoretical in the form of principles, conceptions, views, legal doctrines, and legal methods.

\section{Results and Discussion}

Among those who have supported the fictional character of the legal personality of collective entities, the authoritative figure of Léon Duguit stands out "the theoretical tradition of the state makes it the effective guardian of public order, through the weapon of sovereignty, in order to achieve its general interest purposes". The state was considered an irresponsible juridical person who was not liable for its actions by virtue of the general interests it pursued. On the other hand, the State, from the point of view of private law, is traditionally the subject deemed capable of violating the budget constraint imposed on other associations, by virtue of an ethical prerogative. In fact, the only legitimate legal theory of the state would be that which would make it capable of satisfying the necessary needs of the moment related to social interdependence. For Duguit, the state is a group of men who, through historical evolution, has generated a clear distinction between rulers and governed. According to this theory, the state, stripped of sovereignty, and invested by the duties of pursuing public welfare, would be reduced to the position of private citizen ${ }^{4}$, since it would respond only to the imperative contained in the law. According to other authors, Raymond Saleilles stands out, it would be a historical negation of the

4 J.M. Trigeaud, Justice \& Hègèmonie. La Philosophie Du Droit Face à La Discrimination d'État (Bordeaux: Bière, 2006). 
facts, that of not recognizing its own legal and social autonomy to collective entities ${ }^{5}$. Which, precisely as a function of a decentralization of power, through a demystification of the sovereign functions of the state, declares the autonomy of the existence of collective entities, beyond an original sovereign recognition of the state, or in any case, before this. The unity of purpose and common interests would justify the existence of collective entities, all legitimized by that set of individual wills which, by consecrating the right to free association of individuals, give life to a single collective and communicative will through the functional bodies of the body itself ${ }^{67}$.

In an analysis of the notion of subjective law, which object is fundamental to all the faculties related to legal personality, and which externally affirms itself as a power established by objective law. The subjective right rests on a formal title or investiture and not on the ability to exercise it. In the same way, the collective will of the association, of the company, of the organization, would be represented by organic and functional will put at the service of a common purpose. In order to speak of the subjective right and autonomy of the subject, it is necessary to detect an autonomous power of will, that is, a power that ensures the guarantee of social interests. All subjects endowed with an autonomous will capable of realizing an interest likely to be legally accepted, will be considered as legal persons ${ }^{8}$.

On the basis of this discussion, the idea of personality, in all its meanings, even those that concern the individual, is a specifically juridical reality, which arises from a relationship based on abstraction-not on a fiction-which draws real facts from social reality and translates them into legal terms; it would be to say that it exists in the system provided that certain abstract notions that structure and bind it to social reality are kept in mind. Legal personality is a relationship of this kind: A set of conditions under which it can be affirmed that a subject existing in reality outside the law is legally autonomous. This relationship is not a condition in the natural and innate order, certain relationships between things are established on the basis of an order and a juridical logic that takes inspiration from things, and from the subjectivities, which they themselves order. The juridical conception of the world is only one of its possible definitions and remains an instrument connected to reality through a sectoral logic, the juridical one. In this type of theoretical approach, the autonomy of the collective subject must be traced in its ability to

R. Saleilles, De La Personnalité Juridique (Paris: LGDJ, 2003).

J.J. Bienvenu, "De La Volonté Interne à La Volonté Déclarée: Un Moment de La Doctrine Française," Droits, Revue Française de Théorie Juridique 28 (1999).

7 M. Nicod, De La Volontè Indivuelle (Toulouse: Presses de 1'Universitè Toulouse, 2018).

8 R.A.; L. Farmer and S.E. Marshall Duff, Criminalization: The Political Morality of the Criminal Law (Oxford: Oxford University Press, 2014). 
produce effects as legally and socially relevant facts. To achieve its autonomy, in the sense just described, the entity establishes a relationship with an instrumental element and a subjective element, in such a way that the subjective element is the object that the first aims to produce. In order for a legal entity to exist, there must be a set of relationships, set up with a view to linking an act of will to the same organic set that contributed to producing it.

The two essential elements of legal personality, objective element and subjective element, are not like two extraneous and heterogeneous elements to each other; on the contrary, they are linked in an intimate relationship, which is summarized through the structural and organizational element. Through this synthesis, instrumental power and organic will remain distinct. The power to act in the interest of a subject is attributed through a will that corresponds to it; from this it could be deduced that the split of the two elements would not be necessary and that the will is exactly where the power to act crystallizes. What could be defined as an instrumental part of the institution is its collective organization, whose members who constitute it, considered in an isolated state, no longer have any link that binds them to the organizational unit itself; it is only in the complexity of their mutual relationship that they can count as elements of collective activity, as constituting a legal mechanism. This mechanism behaves in the individual as a functional will, separate from the personal one, even if the act of volition, as an individual psychic act remains of the same nature. Alongside the objective element that creates the corporate unit of the entity, the subjective element reveals its individual part and the plurality underlying the unitary personality. The subjective element is a widespread and collective will. Therefore, it is correct to say that, analytically, the essential elements stand out, and then bind symbiotically in a synthesis that makes them indispensable to each other.

we can speak of "organized irresponsibility" which should oppose a principle of organizational responsibility, capable of directing the current generation towards the survival of the future. The question that concerns is who and how is responsible for certain risks, and to whom and how, to impute the penalties for the relative damages that arise from these risks. This discourse cannot be detached from that concerning the phenomenon of privatization of state benefits. In this context and under these thrusts, the general idea was born according to which everyone must take care of their future responsibly. That is, in a few years it has gone from the welfare state to absolute individual responsibility. Offenses must no longer refer to deficiencies in socialization, or to the class social structure, nor should they induce to set preventive and resocialization measures for the guilty, rather the guilty must again be considered fully responsible 
on an individual level. Circumstances and the environment are less and less important to relieve the individual of his biographical responsibility. Through this trend, civil society, as a society of responsibility par excellence, ends up making the charges immeasurable, absolutizing individual responsibility. In order to escape this danger of paradoxical emptying of individual responsibilities through their absoluteness, on the other hand, it is not possible to resume that opposite direction of pity and assistance "from cradle to grave", and from cradle to crime, up to to the point of relieving the individual of responsibility, thereby depriving him of his freedom. Therefore, the criminal responsibility of organizations has taken on the role of a sort of buffer between the recognition of individual responsibilities and the social insecurity deriving from such recognition. Now, the social state was historically born as a response to the risks that could no longer be mastered by prudence and individual ratio. Through the awareness that the responsibility deriving from accidents, illnesses, unemployment could not be attributed to the individual alone, the idea of a solidarity social guarantee through state insurance ${ }^{910}$.

Now, the departure from this model of care and the consequent individual accountability, on a criminal level, has translated into a departure from the sociotherapy and re-socialization practices that had replaced the punishment, entering the practice of the courts in an individual responsibility tightened. The demystification of individual responsibilities, however, risks creating injustices, as has already been said, as it tends to have repercussions on those who have not adapted to the model, or did not have the possibility of life, or who could not control the variables on which the crime was dependent. Therefore, the devolution of public regulation towards private institutions and organizations, and the self-regulation and self-responsibility of organizations, acts as an important component of a fairer distribution of responsibilities within society $^{11}$. In this perspective, identifying the organizational or individual responsibilities means identifying the interest and function that are at the origin of the crime. Function, as following the logical thread indicated above, these are crimes committed by subjects who play a functional or regulatory role under the pressure of private interests, a phenomenon which, as mentioned, replaces the publicist role in the care of the social functions of the State through the institutionalized implementation of the welfare state. These collective subjects could be considered as private juridical persons who must assume a particular guarantee position with

9 H. Seillan, Dangers, Accidents, Maladies, Catastrophes (Paris: Préventique, 2012).

10 Y. Joseph-Ratineau, La Privatisation de La Rèpression Pènale (Paris: Connaissances et Savoirs, Saint-Denis, 2017).

11 Duff, Criminalization: The Political Morality of the Criminal Law. 
respect to the assets they manage, often demonstrating also a certain technical professionalism of execution. In fact, as private law entities they can legitimately profit from it, but as asset management entities on which the activity can be particularly risky and dangerous for the community, they are obliged to offer compulsory a series of guarantees to protect this last ${ }^{12}$. Public-private cooperation, or almost admixture, gives rise to the problem of the controller. According to public law, it would constitute a system of autonomous rules in order to reconcile the general interest of public authorities and the financial interests of its private partner ${ }^{1314}$. In this context, it is essential, in order to rebalance the system, to establish with the utmost rigor those responsibilities which go beyond the normal personal sphere and which are such as to put individual projects at risk. The traditionally sacrificial nature of criminal law, on the other hand, which places individual effects that originate in a complex and multilevel reality on the individual, finds an element of moderation in the empowerment of collective entities as a technique for recognizing widespread systemic responsibilities, i.e. not individually determinable.

There is a long legal tradition on the predictability of risks which has been fuelled by the issue of industrial and corporate liability: A subject very similar to the sphere of professional liability because there is also a problem of forecasting, predictability, and above all of trust, therefore of guarante $\mathrm{e}^{1516}$. Of course, the correct definition of the risks is fundamental, but this is a function of better defining the predictability of the harmful event, in particular in the complex structures of organizations, among which links can hide, and often there is an interest in hiding, serious risks for the community. The guarantee in this case could be defined as a special protection bond between a guarantor and a legal asset, determined by the owner's total or partial inability to protect it independently. It has also been seen that the guarantee positions can be separated on the basis of a functional classification, on their material content and on the purpose of the position of guarantor, in four basic types: Protection and control position, original guarantee positions and derived.

In particular, reference was made to the underlying relationship between independent

12 J.M. Trigenaud, "Sur La Distinction Civiliste Des Personnes et Des Choses Vvers La Reconnaissance Dì Un Fondement Reel," in Liber Amicorum Bernardo Cremades (Cordoba: Kluwer Law International, 2010), 150.

13 L. Rapp, "Variations Autour de La Personnalitè Juridique En Droit Publique," in Personnalitè Juridique (Paris: Institute Fèdèratif Recherche, 2012).

14 M.C. Amauger-Lattes, La Personnalitè Juridique (Toulouse: Presses de 1'Universitè Toulouse, 2018).

15 M. Bènèjat, La Responsabilité Pénale Professionnelle (Paris: LGDJ, 2012).

16 J. Consigli, "La Responsabilitè Pènale Des Personnes Morales Pour Les Infractions Involontaires: Critères d'imputation," Revue de Science Criminelle et le Droit Pènal Comparè 2 (2014). 
entities that lie beyond the organ-organism relationship, that is, to the other relationship within the entity which is the organization-natural person, which arises through the employment or consultancy contract between body and individuals. Both these categories of subjects do not lend themselves to a traditionally intended application of institutions of guilt and willful misconduct, being professional and corporate crimes closely linked to sector regulations and, as mentioned, to a high specialized standardization. Both professional and corporate crimes would be part of a finalistic conceptualization devoted to sectoral regulation, rather than remuneration in a purely criminal sense based on guilt intended in a dogmatic sense. Finally, there is a common low-wage nature of penalties, which is based on a pragmatic rebalancing of the order compromised by the crime. The most frequent penalties, in these cases, are in fact the real and the disqualification ones, which replace the more traditional imprisonment. In all that has been said so far, it is possible to glimpse how the liability linked to guarantee positions and that attributable to entities, become the real legal institutions driving the new modern criminal law, which is more on the side of regulation than by the repressive one in the strict sense; a criminal law that wants to impose certain taboos and certain forms of solidarity even within complex, qualified, and therefore particularly risky activities.

In a comparative analysis of the legal systems of liability of the entities of the countries, among the most representative of the European area, the hybrid nature of the liability of the entities in Italy was pointed out which, through the legislative decree 231/2001, introduces the administrative liability for crime of legal persons, establishing a formally administrative, but substantially criminal liability. The decree introduced the internal "culture of controls" of companies and the organization and management model aimed at preventing corporate liability from crime, which represents a real innovative turning point in contemporary criminal law. The objective criteria of imputation foresee-as happens, with some variation, in all the other analyzed systems-that a natural person with powers of representation, administration, direction, management, or control, has committed a crime in interest or profit of the institution. The fundamental feature of the Italian system concerns the subjective criteria for imputing liability to entities in which a preponderant role is assumed by the organization and internal management rules of the company and intended to prevent the creation of crimes. In cases where the crimes were committed by persons in top positions, the joint and several liability of the company remains valid, unless the organization and control systems have been fraudulently deceived by the management. While, if the crimes were physically committed by subjects in a para-apical 
position, the adoption and correct implementation of the rules of compliance with the models will represent a cause for exemption from liability, or at least to an attenuation, depending on the cases, for the collective body. This approach is based on a legal reasoning according to which the entity's offense does not end with the crime, but must first of all be sought in a culpable conduct of omitted organization of its activity, according to prevention and rationalization rules suitable to prevent offenses. In this reasoning, which is at the basis of the legislative decree $231 / 2001^{17}$, the offense is only the presupposition of what comes before it, that is, the culpable conduct of the entity; not only is it the basis for a new form of liability, but it is also an independent fact with respect to the crime, which clearly remains only possible with respect to the said culpable conduct of the entity. From this point of view, the reproach that moves the entity is only indirectly linked to the crime, as the latter originates from a culpable conduct of failure to prepare the reference models, a conduct that could be considered even more reprehensible than the crime itself, not only with respect to the potential damage surplus it represents, but also to an assessment based on risk prevention.

In the Italian model, there is a general trend, which is not limited to the question of the criminal liability, or para-criminal liability, of the entities, but which rather regards a subtle tendency to insert the precautionary regulatory principle within a sanctioning logic quasicriminal. This model, entirely built on a highly standardized system of imputation of crimes to the entity, on the basis of a defective organization, has been followed in other legislation, such as that of the United Kingdom ${ }^{1819}$ (Corporate Manslaughter) and Switzerland. Despite this evolution, the entity's subjective liability model, based on preventive organizational models, is still far from a generalization on a European scale. A number of legal systems, and among them some of the most important on a symbolic level, still reject a criminal and subjective notion of corporate liability.

The innovative nature of the reform in France concerning the liability of personnes morales was indisputable ${ }^{20}$. The new Criminal Code finally broke with the societas delinquere non potest principle, which had survived practically uninterrupted from ancient Roman law, except for some minority cases reported by the doctrine. Strongly inspired by a pragmatic

17 M. ; R. Ivory Pieth, Corporate Cirminal Liability. Emergene, Convergence and Risk (Berlin: Springer International Publishing, 2011).

18 C. Wells, "Corporate Criminal Liability in England and Wales: Past, Present and Future," in Ivory, Corporate Criminal Liability. Emergence, Convergence and Risk (Berlin: Springer, 2011), 89.

19 P. Almond, Corporate Manslaughter and Regulatory Reform (Berlin: Springer, 2013).

20 P. Morvan, La Personne Morale Maltraitée Par Le Droit Pénal, in Le Bicentenaire Du Code Pénal (PanthéonAssas, 2010). 
orientation, the French legislator and doctrine have shown themselves to be particularly uninterested in doctrinaire elaborations ${ }^{2122}$. Thus, motivated by reasons of pragmatic criminal criminology, the French legal system took the first steps towards penalizing the liability of entities before many other countries. Based on an anthropomorphic conception of criminal law on the basis of the need to respond to an increasingly dangerous and potentially harmful business crime, especially in environmental matters and in all those sector domains where production risk was tangible, a criminal law developed of the most effective economy in relation to crimes committed physically by natural persons, whose actions or omissions could be attributed to overall decisions coming from the company's management. Little inclined to German dogmatic elaborations ${ }^{232425}$, the French legislator therefore opted for the seemingly simpler solution, as regards the criteria for imputing a crime to entities. A formally criminal indictment system was preferred, by inserting the relevant provisions directly within the Code, and through the potential application of all general offenses envisaged for natural persons, even to personnes morales. The imputation criterion adopted by the French legislator is that of the so-called identification organique, or par ricochet liability, according to which the legal person is liable for the crimes committed by its body or representative, who acted on behalf of the entity. French doctrine and jurisprudence have only recently questioned the systemic coherence of this model. Some authors have recently felt the need to elaborate legal formulations capable of sanctioning a progressive demarcation of the responsibility of the moral person from that of the natural person. Gradually, even in the French legal system, the development of a model based on a guilt of its own in the form of widespread defenses is making headway. First of all, the legislator, through the law 12 July 2000, aimed at reforming the liability for the fault of natural persons, in order to limit the growing imputation of crimes against public authorities, has weakened the relationship between the liability of natural persons and that of personnes morales.

By reforming article 121-3 of the Criminal Code, in which line 4 was added, the natural persons who indirectly caused the damage will not be able to respond for the involuntary

V. Malabat, Les Réformes Du Code Pénal et Du Code de Procédure Pénale (Paris: Dalloz, 2009).

22 M. Giacopelli, "Les Procèdures Alternatives Aux Poursuites. Essai de Thèorie Gènèrale," Revue de Science Criminelle et le Droit Pènal Comparè 3 (2012): 508.

23 G. Dannecker, "Zur Notwendigkeit Der Einführung Kriminalrechtlicher Sanktionen Gegen Verbände," Goltdammer's Archiv für Strafrecht 148 (2001).

24 P. ; P. Albrecht and F. Bommel Aebersold, Beiträge Grundfragen Eines Zeitgemässen Strafrechts (Baden Baden: Stämpfli, Nomos Verlag, 2017).

25 J.C. Sola, “Culpalidad, Identidad y Organizaciòn Colectiva,” Politica Criminal 12 (2017). 
crime $^{26}$, unless they are held responsible for fault specific or conscious. While for legal persons a simple fault will be sufficient to integrate the criminal charge ${ }^{27}$. Finally, the same jurisprudence, more recently, has taken small steps towards the recognition of an autonomous fault based on company policy, for example in the field of voluntary crimes related to financial fraud ${ }^{282930}$; and with regard to culpable crimes, for example for the death of patients within hospital companies ${ }^{31}$. All these jurisprudential attempts collide with a certain resistance on the part of the Court of Cassation, which prefers an original interpretation of the texts that would be linked to the model based on organic identification ${ }^{32}$.

An analysis of the discipline contained in the German legal system also seemed indispensable, not only for the rich doctrinaire debate that characterized the issue of corporate liability in criminal law, but also because the German legislator still refuses to overcome the ancient principle societas delinquere non potest. The German system is, in fact, among the countries that have not yet adopted a criminal liability of entities, nor a hybrid liability. A choice evidently dictated by the dogmatic complexity of an order particularly linked to a systematic and principled juridical conception. Germany recognizes, however, the applicability of a number of financial penalties to legal entities. Based on art. $75 \mathrm{StGB}$, the assets of a legal person can be confiscated when it is recognizable as an instrument or product of the crime ${ }^{33}$.

In any case, it is not a matter of applying penalties in the strict sense, these measures simply aim to remove the means or products resulting from the crime from the company, measures which, moreover, seem to have a formally preventive scope, without any declaration of guilt. On the other hand, German legislation admits that a legal person can be called to answer for certain administrative infringements. It is a system of fines which is based on an imputative parameter based on a model, once again, of organic identification, on the basis of which it is established that the infringement must be the material work of a representative or manager of the

26 É. De La Boètie, Discours de La Servitude Volontaire (Paris: 1001 Nuits, 2011).

27 G. Giudicelli-Delage, "La Responsabilitè Dans l'entreprise Après La Loi Du 10 Juillet 2000," Revue Science Criminelle 11 (2001): 824.

28 F. Stasiak, "Responsabilitè de La Personne Morale," Revue Science Criminelle 10 (2010): 165.

29 N. and A. Reygrobellet Huet, La Rèforme Du Contantieux Boursier. Rèpression Des Abus de Morachès En France et Solutions Ètrangèeres (Bruxelles: Larcier, 2016).

30 J. Tricot, "Le Droit Pènal à l'èpreuve de La Responsabilitè Des Personnes Morales: L'example Français," Revue de Science Criminelle et le Droit Pènal Comparè 1 (2012): 22.

31 Y. Mayaud, "Responsabilitè Pènale d'un Cente Hospitalier Universitaire Pour Dèfaut d'organisation," Revue Science Criminelle (2010): 618.

32 J.H. Robert, "Homicide Involontaire à La Charge d'une Personne Morale: Frein, Mais Mon Fin de La Jurisprudence Relative à Son Imputation Prèsumèe," Revue Science Criminelle (2012): 825.

33 B. Hecker, Europäisches Strafrecht (Berlin: Springer, 2012). 
entity, in the exercise of his functions, and that this action has brought an advantage for the legal person. Germany thus continues to maintain a model based on the societas delinquere non potest principle, by virtue of a strong roots in the traditional principle of guilt as an essential foundation of criminal responsibility.

The Spanish legislator, on the contrary, has chosen to include the criminal liability of legal persons within the same Criminal Code, as in France, in order to respect the international obligations contracted and refuting any doubt about its orientation, opting for a qualification declaredly criminal liability of entities. From the imputation point of view, article 31 bis of the Criminal Code requires, for its application, also the action of a natural person, or the so-called fact of connection ${ }^{34}$. In this regard, on the one hand the offense is required to be materially related to the commission or omission by the middle managers, but it is possible that the action or omission of a subordinate is relevant in this sense if it is shown that the facts arose thanks to a defect in the control and management obligations. More generally, the system created by the Spanish legislator aims to encourage procedural collaboration between companies and the State in order to discover and punish the crimes committed within the company organization, and, at the same time, reward the adoption of preventive business models. organization. In summary, this is a model of corporate liability that is still evolving where it is possible to observe a desired progress towards a personal character of corporate criminal law, but not sufficient to stem the tendency to penalize disobedience tout court to regulations ${ }^{3536}$.

Finally, Belgium represents a particularly rigorous, not to say rigid, system in the application of criminal liability to entities. It privileged a model of direct criminal liability of entities $^{3738}$, which is not conditioned, at least in principle, by the identification of the natural persons who acted in the name or on behalf of the legal person. One of the first questions that the Belgian legislator had to face was that of making a choice between a fictional conception of the legal nature of the entity, and a conception that in Belgium is called the theory of technical reality, according to which the institution has a its real consistency, distinct from that of the members, which allows it to make autonomous decisions and to pursue the objectives that it sets.

34 Ibid.

35 M. Gòmez Tomillo, Introducción a La Responsabilidad Penal de Las Personas Jurídicas En El Sistema Español (Valladolid: Lex Nova, 2010).

36 A. Roma Valdès, Responsabilidad Penal de Las Personas Juridicas: Manual Sobre Su Tratamiento Penal y Procesal (Madrid: Rasche, 2012).

37 O. Creplet, "Propos Sur La Nature de La Responsabilitè Morale de La Personne Morale," Journal des Tribunaux (2011): 478.

38 C. Van De; S. Vandromme and P. Traest Wyngaert, Strafrecht En Strafprocessrecht Im Hoofdlijnen (OutTurnhout: Gompel \& Svacina, 2019). 
It is the latter decision that the legislator has taken ${ }^{39}$. We have chosen to adopt a series of security measures by opting decidedly for a criminal liability system, assimilating the legal entity's doing and omitting to that of the natural person. It has been argued that a harmful fact can be directly attributed to the legal person and, therefore, that the latter is endowed with the ability, albeit specific, to understand and want, required for a correct criminal charge. By basing the liability of legal persons on classically criminal parameters, the legislator tried to comply with the rules of the principle of personality of criminal liability, immediately excluding indirect criminal liability for acts committed by third parties ${ }^{4041}$; fact that obliges the judges of merit to verify from time to time the existence of the constituent elements of the crime of the legal person, and it is not a question of simple correspondence or not to the established regulatory models, but to the finding of guilt subjectively understood. Due to the strong orthodoxy devoted to a deeply anthropomorphic conception of the entity's juridical personality in Belgium, some authors wonder if the organizational fault has not become a fault in itself, different from the crimes to which it refers, constituting itself a separate crime, regardless of the imputation of the crime attributable to the person. We cannot ignore the complexity of the profiles that should be assessed and the numerous difficulties to be faced related to the profound and persistent European differences with regard to criminal legislation, if one wanted to hypothesize the possibility of harmonization. The major differences are manifested above all between systems that are inspired by accentuated pragmatism (France, Belgium) and systems that are based on a tradition more sensitive to conceptualizations and systematic categories in the definition of criminal phenomena (Italy, Germany, Spain). But beyond the aforementioned general differences between European legal systems, there are many others, more specific, which would require extreme prudence in a desirable elaboration of harmonization on the matter. These differences, moreover, do not prevent from highlighting a series of basic characteristics common to the different systems. In fact, all European legal systems now refer, albeit with a different indicative value, to crime prevention models and sectoral codes of conduct for businesses. Starting from the observation that the entity, for the activities it carries out, can be considered as the subject in the original position of guarantee and control over third parties, who do not have an independent possibility of protection, therefore, substantially incapable. A common model could be founded

39 Creplet, "Propos Sur La Nature de La Responsabilitè Morale de La Personne Morale."

40 F. Kuty, Principes Généraux de Droit Pénal Belge, t. III, L'auteur de l'infraction Pénale (Bruxelles: Larcier, 2012).

41 J. Vanden Eynde, La Responsabilitè Civile et Pènale Des Administrateurs et Membres Du Comitè de Direction Des Societès Anonymes: Introduction (Paris: Anthemis, 2017). 
precisely by the development of common guidelines of the disciplines by sector of activity. In fact, given the particularly technical nature of the content of the so-called guidelines, they would have a sufficiently universalizing and not very political character, so it would not be difficult to agree on this the different European criminal orders. At a second level, legislative intervention by the European Union ${ }^{4243}$ in one of the sectors of predominant international interest (organized crime, money laundering, corruption, etc.) would be desirable, with the aim of establishing a compliance program in order to prevent certain crimes and to determine, in the sector of reference, the criteria for imputing criminal or para-criminal liability for entities. For example, initially one could only intervene on the shortcomings and shortcomings of the individual Member States, constituting a sort of added value to the repressive systems already used by national laws.

\section{Conclusions}

Considering the transnational character of certain criminal phenomena, an innovative intervention by the Union should first of all aim at preventing the perpetrators of the crime from taking advantage of the differences existing between the repressive systems; also for this reason cooperation should be encouraged. In order to be effective, cooperation requires common minimum standards which, although they do not imply complete harmonization, on the other hand require that criminal behaviour be clearly defined in accordance with the principle of sécurité juridique. Following the principles set by the European Commission in the perspective of harmonization, the problem that seems to be emerging is that of better defining how the common denominators of European criminal laws in the sectors considered can arrive at an acceptable synthesis. In this sense, the resistance to a full establishment of the criminal liability of entities in Europe is concentrated above all on the problem of the nature of this liability and, consequently, on those conditions which ensure the legitimacy of a sanctioning regime which, for its intrinsic severity risks, if not well articulated and defined, of infringing the fundamental personality principles of criminal responsibility, both from an objective and a subjective point of view. It is necessary to see to what extent the criminal liability of the entities constitutes, or not, an attribution of responsibility for the other person's done or, in any case, an objective attribution

42 L. and M. Munoz De Morales Romero Arroyo, "Droit Pénal Européen et Traité de Lisbonne: Le Cas de l'harmonisation Autonome (Art. 83.1 TFUE)," in Le Droit Pénal de l'Union Européenne Au Lendemain Du Traité de Lisbonne (Paris: Sociètè de Lègislation Comparèe, 2012), 113.

43 M. and W.C. Gilmore Fletcher, EU Criminal Law and Justice (Cheltenham: Edward Elgar Publishers, 2010). 
of responsibility. In other words, we need to build a model that marginalizes the risk of strict liability, so that the doubts still posed by many countries are eliminated, with a view to full and convinced compliance with criminal or para-criminal regulation of legal persons. One of the main themes is, therefore, that of guarantees proper to criminal law and trial. The European Union model, at least the one proposed to date, does not seem to respond adequately to these needs so far. The directive of 5 April 2011 on trafficking human beingsdefines the liability of entities in relation to the top positions of individuals; or to other bodies which, although not top management, act on behalf of the legal person. The directive also mentions another requirement, according to which the infringement must result from the violation of the company's internal control obligations. Here, the subjective position of the author as a natural person and the causal dependence of the control defect are purely objective elements. The quid pluris, which characterizes the criminal liability of entities and distinguishes it from that of natural persons acting on their behalf, is not adequately considered. In this way, it is not possible to attribute to the legal person a subjective attitude that is proper to it. In order to attribute a specific and subjective responsibility to the legal person, it is necessary to find an imputation model different from that applied to the body of the entity, author of the infringement. It is necessary to study the extent to which this purpose can be achieved through the development of imputation criteria based on sector compliance programs and crime prevention models. In particular, taking into account the regulatory tools already developed by the Union, the national differences between the member countries and the theories set out in the course of this discussion on liability based on guarantee and control positions; but above all considering the character of the crimes of the legal person as particularly linked to the type of activity it undertakes. At this point, the responsibility of the entities could be established on a series of guiding criteria: 1) The position of the material author, of the natural person, in a direct functional relationship with the organization of the entity. That is, the natural person is subject to obligations, functions, and regulations that, in relation to the specific activity carried out, aim to make him assume a position of guarantee with respect to the compromised asset and in that sector, a guarantee that refers to that of the entity, as original; 2) The crime, or the infringement, must occur following an organizational gap in the company; 3) Before the commission of the offense, it had to be foreseeable and avoidable, according to the regulations concerning the business activity of the company, or on a general requirement of behaviour of the entity in relation to the protection of the assets on which it is required to guarantee the security. Last but not least, the proliferation 
and rationalization of codes of conduct for companies and sector codes ${ }^{4445}$, by European governments more aware of the emergence of a new criminal law of the economy and business, represent important indicators of the recognition of the legal personality of entities and the need to standardize the matter at European level.

\section{References}

Aebersold, P.; P. Albrecht and F. Bommel. Beiträge Grundfragen Eines Zeitgemässen Strafrechts. Baden Baden: Stämpfli, Nomos Verlag, 2017.

Almond, P. Corporate Manslaughter and Regulatory Reform. Berlin: Springer, 2013.

Amauger-Lattes, M.C. La Personnalitè Juridique. Toulouse: Presses de l'Universitè Toulouse, 2018.

Arroyo, L. and M. Munoz De Morales Romero. "Droit Pénal Européen et Traité de Lisbonne: Le Cas de l'harmonisation Autonome (Art. 83.1 TFUE)." In Le Droit Pénal de l'Union Européenne Au Lendemain Du Traité de Lisbonne, 113. Paris: Sociètè de Lègislation Comparèe, 2012.

Bènèjat, M. La Responsabilité Pénale Professionnelle. Paris: LGDJ, 2012.

Bienvenu, J.J. "De La Volonté Interne à La Volonté Déclarée: Un Moment de La Doctrine Française." Droits, Revue Française de Théorie Juridique 28 (1999).

Boètie, É. De La. Discours de La Servitude Volontaire. Paris: 1001 Nuits, 2011.

Boulanger, A. Restrucurations Sociètaires et Responsabilitè Pènale. Toulouse: Presses de l’Universitè, 2019.

Consigli, J. "La Responsabilitè Pènale Des Personnes Morales Pour Les Infractions Involontaires: Critères d'imputation." Revue de Science Criminelle et le Droit Pènal Comparè 2 (2014).

Creplet, O. "Propos Sur La Nature de La Responsabilitè Morale de La Personne Morale." Journal des Tribunaux (2011): 478.

Dannecker, G. "Zur Notwendigkeit Der Einführung Kriminalrechtlicher Sanktionen Gegen Verbände." Goltdammer's Archiv für Strafrecht 148 (2001).

Duff, R.A.; L. Farmer and S.E. Marshall. Criminalization: The Political Morality of the Criminal Law. Oxford: Oxford University Press, 2014.

Eynde, J. Vanden. La Responsabilitè Civile et Pènale Des Administrateurs et Membres Du

\footnotetext{
${ }^{44}$ Hecker, Europäisches Strafrecht.

${ }^{45}$ B. Hecker, op. cit.
} 
Comitè de Direction Des Societès Anonymes: Introduction. Paris: Anthemis, 2017.

Fletcher, M. and W.C. Gilmore. EU Criminal Law and Justice. Cheltenham: Edward Elgar Publishers, 2010.

Giacopelli, M. "Les Procèdures Alternatives Aux Poursuites. Essai de Thèorie Gènèrale.” Revue de Science Criminelle et le Droit Pènal Comparè 3 (2012): 508.

Giudicelli-Delage, G. "La Responsabilitè Dans l'entreprise Après La Loi Du 10 Juillet 2000." Revue Science Criminelle 11 (2001): 824.

Hecker, B. Europäisches Strafrecht. Berlin: Springer, 2012.

Huet, N. and A. Reygrobellet. La Rèforme Du Contantieux Boursier. Rèpression Des Abus de Morachès En France et Solutions Ètrangèeres. Bruxelles: Larcier, 2016.

Joseph-Ratineau, Y. La Privatisation de La Rèpression Pènale. Paris: Connaissances et Savoirs, Saint-Denis, 2017.

Kuty, F. Principes Généraux de Droit Pénal Belge, t. III, L'auteur de l'infraction Pénale. Bruxelles: Larcier, 2012.

Malabat, V. Les Réformes Du Code Pénal et Du Code de Procédure Pénale. Paris: Dalloz, 2009.

Mayaud, Y. "Responsabilitè Pènale d'un Cente Hospitalier Universitaire Pour Dèfaut d'organisation." Revue Science Criminelle (2010): 618.

Morvan, P. La Personne Morale Maltraitée Par Le Droit Pénal, in Le Bicentenaire Du Code Pénal. Panthéon-Assas, 2010.

Nicod, M. De La Volontè Indivuelle. Toulouse: Presses de l’Universitè Toulouse, 2018.

Pieth, M.; R. Ivory. Corporate Cirminal Liability. Emergene, Convergence and Risk. Berlin: Springer International Publishing, 2011.

Rapp, L. "Variations Autour de La Personnalitè Juridique En Droit Publique." In Personnalitè Juridique. Paris: Institute Fèdèratif Recherche, 2012.

Robert, J.H. "Homicide Involontaire à La Charge d'une Personne Morale: Frein, Mais Mon Fin de La Jurisprudence Relative à Son Imputation Prèsumèe.” Revue Science Criminelle (2012): 825 .

Saint-Pau, J.CH. 9 ed0. Traité Des Droits de La Personnalité. Paris: LexisNexis, 2013.

Saleilles, R. De La Personnalité Juridique. Paris: LGDJ, 2003.

Seillan, H. Dangers, Accidents, Maladies, Catastrophes. Paris: Préventique, 2012.

Sola, J.C. “Culpalidad, Identidad y Organizaciòn Colectiva.” Politica Criminal 12 (2017).

Stasiak, F. "Responsabilitè de La Personne Morale.” Revue Science Criminelle 10 (2010): 165. 
Tomillo, M. Gòmez. Introducción a La Responsabilidad Penal de Las Personas Jurídicas En El Sistema Español. Valladolid: Lex Nova, 2010.

Tricot, J. “Le Droit Pènal à l'èpreuve de La Responsabilitè Des Personnes Morales: L'example Français.” Revue de Science Criminelle et le Droit Pènal Comparè 1 (2012): 22.

Trigeaud, J.M. Justice \& Hègèmonie. La Philosophie Du Droit Face à La Discrimination d'État. Bordeaux: Bière, 2006.

Trigenaud, J.M. "Sur La Distinction Civiliste Des Personnes et Des Choses Vvers La Reconnaissance Dì Un Fondement Reel.” In Liber Amicorum Bernardo Cremades, 150. Cordoba: Kluwer Law International, 2010.

Valdès, A. Roma. Responsabilidad Penal de Las Personas Juridicas: Manual Sobre Su Tratamiento Penal y Procesal. Madrid: Rasche, 2012.

Vàszquez, M.A. Abanto. "Responsabilidad Penal de Los Entes Colectivos: Una Rèvision Critica de La Soluciones Penales.” Revista Penal Mèxico 3 (2010): 124ss.

Wells, C. "Corporate Criminal Liability in England and Wales: Past, Present and Future." In Ivory, Corporate Criminal Liability. Emergence, Convergence and Risk, 89. Berlin: Springer, 2011.

Wyngaert, C. Van De; S. Vandromme and P. Traest. Strafrecht En Strafprocessrecht Im Hoofdlijnen. Out-Turnhout: Gompel \& Svacina, 2019. 